\title{
NORTH AMERICAN SPECIES OF THE WEEVILS OF THE OTIORHYNCHID GENUS MESAGROICUS
}

\author{
By L. L. Buchanan, \\ Of the United States Biological Survey
}

Up to the present time the weevil genus Mesagroicus has been recorded only from the palaearctic regions, where a total of about 20 species are known. The single hitherto described American species is herricki Pierce, for which its author proposed the unnecessary generic name Lepidocricus - herricki being closely related to a rather common European species, Mesagroicus obscurus Boheman. ${ }^{1}$ Pierce's description of Lepidocricus herricki, together with two or three subsequent references to it, comprise the entire American literature on the group.

It was of especial interest, therefore, to find among some undetermined material in the United States National Museum collection a considerable number of North American specimens belonging to Mesagroicus. These specimens represent several well-marked species, widely distributed over the United States, and doubtless present, in greater or less numbers, in every large beetle collection of the country. Under the circumstances, it seemed worth while to undertake a revisional study of all our native species, in order that a widespread but almost wholly neglected element of the North American weevil fauna may be more generally recognized.

The material examined is largely from the collection of the United States National Museum, supplemented by a number of specimens received from other sources. The writer is indebted in particular to H. F. Wickham and E. T. Cresson, jr., for the loan of material, and to Mary Foley Benson, of the Bureau of Entomology, for the carefully prepared and characteristic drawings of herricki and elongatus. Types of the species here described as new are deposited, one in the Philadelphia Academy, the remainder (eight) in the National Museum.

\section{Genus MESAGROICUS Schönherr}

Mesagroicus SснӧNherR, Gen. et Sp. Curculionidum, vol. 6, part 1, 1840, p. 281

(Genotype, Thylacites piliferus Boheman as designated by Schönherr).Lacordaire, Gen. Col., vol. 6, 1863, p. 72.-Jacquelin du VaL, Gen. des Col.

${ }^{1}$ Twelve exotic species of Mesagroicus have been examined; two or three of them show a striking superficial resemblance to some of the American species, but no case of actual identity was observed.

No. 2801.-Proceedings U. S. National museum, Vol. 76, Art. 4

$41437-29$ 
d'Europe, 1868, p. 18 (figure of Mesagroicus obscurus Boheman, pl. 30, fig. 146).-Gemmanger and Harold, Catalog Coleop., vol. 8, 1871, p. 2203.Redtenbacher, Fauna Austriaca: die Käfer, part 2, 1874, p. 196 and CXxxi.Reitter, Bestim. Tab. eur. Coleop., heft 52, Paskau, 1903.

Lepidocricus Pierce, Journ. Econ. Ent., vol. 3, 1910, p. $362 . \quad$ (Genotype, herricki

Pierce, Journ. Econ. Ent., vol. 3, 1910, p. 362, as designated by Pierce).-

Blatchley and Leng, Rhyn. of N. E. Amer., 1916, p. 126.-Leng, Cat. Coleop., 1920, p. 314.

Mesagroicus includes rather small (3 to $6 \mathrm{~mm}$. long) plain-looking beetles, with no marked structural or habital peculiarity. The following features are those which have proved useful for recognizing members of the genus: The Sitona-like appearance of the head, due to the rounded, convex eyes, the quadrangular, medially grooved rostrum, and the lateral, strongly arcuate scrobes; the unusually short fifth ventral segment; and the rather stout antennae. About half the species (eastern) have a tuberculate pronotum; the remainder (western) have more or less perfectly developed plumose scales on the abdomen. The fore and mid tibiae are generally denticulate along inner edge. The humeri are broadly rounded, and the elytra much wider than the rather small prothorax. Metathoracic wings rudimentary. The punctures on third, fourth, and fifth ventral segments are often much finer and denser than on the first two. With free claws, a scaly and setose body, and lacking prothoracic ocular lobes and vibrissae, Mesagroicus traces to the vicinity of Pantomorus and Artipus, differing from the former by the shorter second funicular segment, etc., and from the latter by the free outer striae of elytra, etc. Other characters are mentioned in the key or illustrated by outline drawings. An erroneous statement in Pierce's generic diagnosis $(1910$, p. 362) should be corrected here. The rostrum is said to be separated from the head beneath "by very sharp and deep constriction," but, as a matter of fact, the junction of these parts is perfectly normal-about as in Epicaerus or Pantomorus.

There seem to be no dependable external marks for distinguishing the sexes. When a series of both are present, the males can generally be told by their smaller size, narrower form, more slender beak, longer mucro on hind tibia, and better defined concavity on base of abdomen; the females by their distinctly shorter prothorax and by the transverse concavity on fifth ventral. The latter character, though variable in development and even slightly indicated on occasional male specimens, is perhaps the one most useful for separating the sexes. The tibial mucro is found on all three pairs of legs in the male, and at least on first and second in female; on the hind pair of female it may be present or absent on different specimens of the same species. The median lobe of the male genitalia in the different species shows slight but apparently constant differences. 


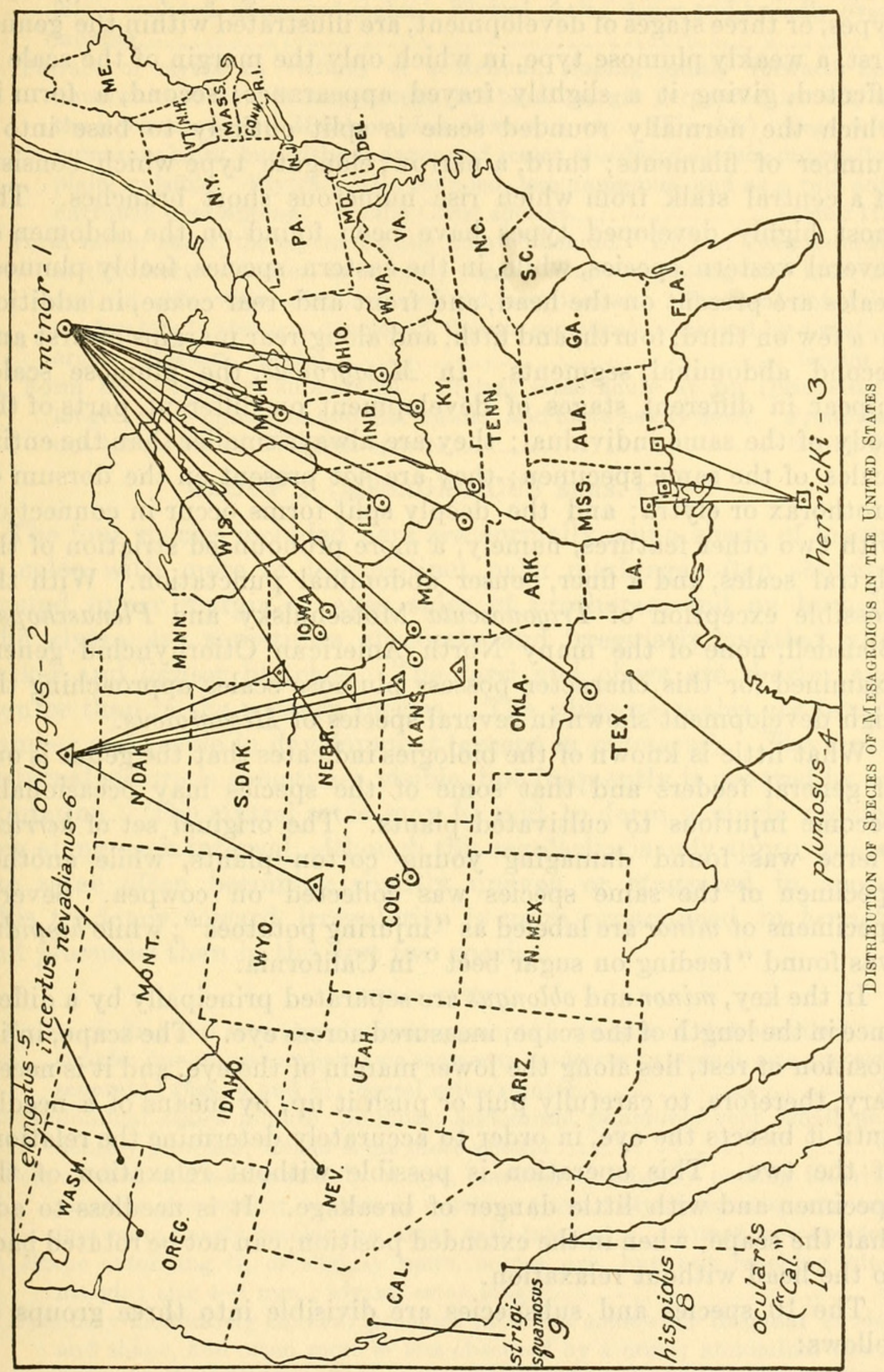


In all the species the scales on certain regions of the body are modified by a more or less complete splitting process, resulting in what are here termed plumose scales. ${ }^{2}$ Roughly speaking, three types, or three stages of development, are illustrated within the genus; first, a weakly plumose type, in which only the margin of the scale is affected, giving it a slightly frayed appearance; second, a form in which the normally rounded scale is split entirely to base into a number of filaments; third, a narrow, elongate type which consists of a central stalk from which rise numerous short branches. The most highly developed types have been found on the abdomen of several western species, while, in the eastern species, feebly plumose scales are present on the head, and front and rear coxae, in addition to a few on third, fourth, and fifth, and along rear margins of first and second abdominal segments. In Mesagroicus, the plumose scales appear in different stages of development on different parts of the body of the same individual; they are always smaller than the entire scales of the same specimen; they are not present on the dorsum of prothorax or elytra; and the deeply split forms occur in connection with two other features, namely, a more pronounced striation of the elytral scales, and a finer, denser abdominal punctation. With the possible exception of Trigonoscuta Motschulsky and Plenaschopsis Blaisdell, none of the many North American Otiorhynchid genera examined for this character possess plumose scales approaching the high development shown in several species of Mesagroicus.

What little is known of the biologies indicates that the genus is one of general feeders and that some of the species may occasionally become injurious to cultivated plants. The original set of herricki Pierce was found damaging young cotton plants, while another specimen of the same species was collected on cowpea. Several specimens of minor are labeled as "injuring potatoes"; while hispidus was found "feeding on sugar beet" in California.

In the key, minor and oblongus are separated principally by a difference in the length of the scape, measured across eye. The scape, in its position of rest, lies along the lower margin of the eye, and it is necessary, therefore, to carefully pull or push it up, by means of a needle, until it bisects the eye, in order to accurately determine the relations of the two. This operation is possible without relaxation of the specimen and with little danger of breakage. It is needless to add that the scape, when in the extended position, can not be rotated back to the head without relaxation.

The 10 species and subspecies are divisible into three groups as follows:

${ }^{2}$ Scales of this or a similar nature, which are present on many weevils, have been variously called feathery, plumose, plumate, split, multifurcate, or shaggy by different writers. 
1. Basal margin of elytra (the deflexed portion extending downward to the mesonotum) perpendicular, or nearly so, from side to side-about as in Tanymecus confertus. (Fig. 17.) Legs setose and also with a coating of large, rounded, appressed scales. Elytral scales dense and broadly overlapping _._.

1a. Surface of elytra, in vicinity of scutellum, sloping gently forward and downward to level of mesonotum, the basal margin perpendicular only at the sides, about as in Melamomphus alternatus, etc. (Fig. 18.) Legs with numerous hairs, but without appressed scales, the dense surface punctation plainly visible. Elytral scales rounded, less numerous, and as a rule only narrowly overlapping. Pacific Coast species_........... Group III.

2. Form rather stout, the elytra slightly inflated behind. Elytral setae truncate at tip, shorter, stouter, in a nearly regular single row along each interval, and, in side view, distinctly curved and inclined. Pronotal tubercles moderately to strongly developed, though sometimes obscured by a surface crust. Eastern species _...

2a. Form more slender, subparallel. Elytral setae acute at tip (bristlelike), longer, more numerous and less regular, and more nearly erect. Pronotum

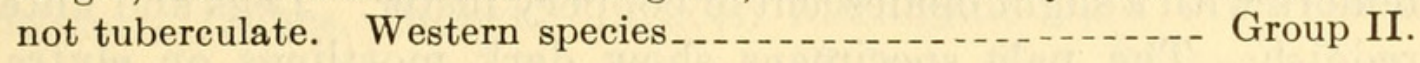

\section{GROUP I (MESAGROICUS sens. str.)}

The four species included here are normally some shade of brown in color, with more or less distinct paler markings often showing around upper margin of eyes, sides of prothorax, and on humeri. The elytra are sometimes obscurely and irregularly mottled with darker and lighter blotches. The tarsi and claws are shorter and stouter than in the western species. The plumose scales are few in number and feeble in development (except in plumosus). The metepisternal suture is sometimes visible, but frequently is covered by an exudation. The elytral setae may be said to form a single regular row along each interval, although this regularity is only approximate, the setae often becoming slightly uneven or staggered in spots. This tendency toward irregularity is more pronounced in herricki and plumosus than in the first two species.

1. Scales on first and second abdominal segments large (size of elytral scales) and simple; punctures on these two segments moderate to large in size and well separated (figs. 4 and 5); dorsal setae stouter_._............. 2.

1a. Abdominal scales minute, plumose; abdominal punctures very small and

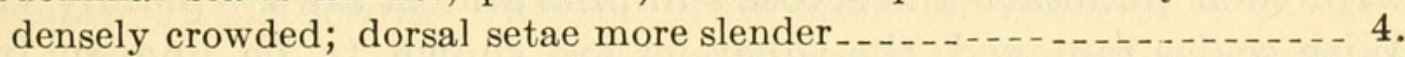

2. Scape, when laid across middle of eye, reaching or slightly passing its hind margin; size smaller, seldom as much as $4 \mathrm{~mm}$.; elytral setae shorter and in a more nearly regular row along each interval .... minor, new species.

$2 a$. Scape extending $3 / 4$, or slightly more, across eye, but not reaching hind margin; size 4-6 mm.; elytral setae longer................. 3.

3. Eyes only moderately convex; pronotal tubercles somewhat irregular in size and shape, and often more or less obscured by a crust; abdominal punctures smaller; pronotum more transverse (25 to 18 in male; 28 to 20 in female-average of 6 specimens of each sex); Middle Western States.

oblongus, new species. 
$3 a$. Eyes generally very prominent; rostral sculpture coarser and deeper; pronotal tubercles forming about a hemisphere and nearly always sharply isolated; pronotum less transverse ( 23 to 19 in male; 27 to 21 in female-average of 6 specimens of each sex); South Atlantic region_.... herricki Pierce.

4. Eyes large; prothorax relatively small and with conspicuous tubercles. Texas. plumosus, new species.

MESAGROICUS MINOR, new species

Eighty-five specimens. Length, 3-4.2 mm. Width, 1.4-2.1 mm. Oblong, scaly covering dense, often also with a thin crust or exudation which more or less obscures the pronotal tubercles and the individual scales of elytra. Scales brown, dorsum of elytra often with some irregular pale and dark blotches, the pale areas rarely extending over most of the upper surface; a band around upper margin of eyes, sides of prothorax, humeral spot, margins of elytra, and undersurface generally paler. Scales on undersurface and on femora with a slight opalescent or coppery luster. Legs and antennae reddish. The pale specimens show dark mottlings on elytra and dark median and sublateral prothoracic stripes. Base of prothorax with a narrow, collarlike constriction extending partly or wholly across dorsum.

Rostrum as long as exserted portion of head, quadrangular in cross section, nearly flat to more or less deeply concave from eyes at least as far forward as the antennal insertion, and also with a narrow median groove which may or may not be continued up on to front of head; nasal plate feeble, surface behind it subglabrous and coarsely sculptured. Sculpture of head and beak, with scales removed, dense and more or less strigose; setae more numerous along sides of rostral sulcus and in a patch above eye. Eyes moderately to strongly prominent, subcircular to oval. Scape feebly biarcuate, slender in basal $3 / 4$, distinctly enlarged apically ; first funicular segment stouter, $1 / 3$ to $1 / 2$ longer than second, the latter longer than broad, third to seventh moniliform, seventh broader than sixth but, as a rule, not strongly transverse. Sides of prothorax strongly rounded in female, less so in male, fore and hind margins subtruncate, apex feebly constricted or not; pronotal tubercles small, generally obscured by the crust, but with their punctate and setose summits almost always plainly visible. With scales removed, the tubercles are shown to be uneven in size and shape, with a tendency to run together, some of them formed by the coalescence of several very small tubercles. Elytra with base distinctly emarginate, humeri rounded and merging into the slightly arcuate sides; scutellum minute or invisible, sutural interval sometimes slightly elevated for a short distance near base; elytra not striate, but with regular rows of large, close-set punctures that are so nearly concealed by the scales and crust that they appear as minute black dots; intervals nearly flat, each with a regular row of short setae that are separated by their own length or more; when 
denuded, the intervals show a ininute but rough punctulation. Abdominal punctures on 1 and 2 larger in male, the shining intervals punctulate and reticulate. Fifth ventral finely and densely punctate. Femora stout, tibiae rather slender, especially in male, anterior pair nearly straight along exterior edge, distinctly bisinuate on inner. Tarsi stout, claws large, metepisternal suture visible or not. Female with a usually distinct transverse depression on fifth ventral. A few feebly plumose scales are present on undersurface and vertex of head, on collarlike production of mesosternum, on fore and rear coxae, etc.

Type-A male (Cat. No. 41746, U.S.N.M.), $3.6 \mathrm{~mm}$. long, with elongate eyes and distinct rostral sulcus, and 55 paratypes.

Type locality.-Kansas (injuring potato).

Other localities: Kansas (Topeka, Popenoe); Missouri (St. Louis, Soltau), (Kansas City, Soltau), (Cadet, Barlow); Iowa (Iowa City, Wickham), (Ames, Stoner); Illinois; Michigan; Ohio (Cincinnati, Dury); Kentucky (Louisville, Soltau), (Fulton, G. I. Reeves); Texas (Dallas, C. E. Hood); Colorado (Sedalia, Soltau).

Nearly all the external structures of minor are subject to considerable or even excessive variation, making it difficult to describe the species in any but indefinite language, or to select key characters that are likely to prove invariably trustworthy. The variations, though so extreme, appear to be true individual differences, since they are not correlated with any marked difference in habitat, and are not substantiated by tangible genitalic differences. Two of the more striking variations affect the eye and the rostral sculpture. The outline of the eye varies from a nearly circular to a distinctly elongateoval form, with all intergradations. Females show a tendency toward the circular, males toward the oval, type; but there is no constancy in this respect, and individuals of either sex can be found with either form of eye. On the average, the male eye is slightly larger, compared to bulk of head, than in female. The upper surface of beak varies from nearly flat with a fine median groove to broadly and deeply concave; the concavity may end abruptly opposite antennal insertion or may extend nearly to apex. The funicular segments also show inconstancy, the second varying from short and heavy to elongate, though it is never as long or as thick as the first; the seventh segment, in a few specimens, is nearly twice as broad as is normal. The impression on fifth ventral of female is typically rather deep, but becomes shallow in some specimens and, moreover, may be faintly indicated in the male. More or less variation has been noted also in the length of the elytral setae, the thickness of the tibiae, the relative dimensions of the prothorax (irrespective of sex) and the development of the pronotal tubercles. In one or two specimens the abdominal punctures are nearly as large as in herricki. 
The species collected by Dury at Cincinnati, Ohio, and distributed as herricki Pierce, belongs here. The Cincinnati specimens examined are not typical in some respects (the body being stouter, the scape slightly shorter, and the elytral setae longer) and possibly may indicate a local race. The male genitalia, however, are of the normal minor form.

The crust or exudation is more pronounced in minor than in any of the other species.

MESAGROICUS OBLONGUS, new species

Forty-six specimens. Length, 4-5 mm. Width, 2.01-2.5 mm. Close to minor in structure and appearance, but larger. Brown, pale markings as in minor, and in addition some specimens with feeble vittae on sutural, third and fifth intervals. Legs, antennae, and often tip of beak, reddish. Scales of ventral surface and legs slightly opalescent. Sculpture of head rather fine, subconfluent, finer than in minor; rostrum nearly flat above, with a narrow to coarse median groove which may or may not extend on to head. Rostral sculpture more or less strigose, as in minor. Eyes moderately prominent, oval to subcircular. Prothorax relatively shorter, male and female, than in minor, the pronotal tubercles larger and better defined, and occasionally leaving a narrow median line free; base with a narrow collar, about as in minor. Elytra about as in minor, sides straighter, setae slightly longer on the average, the individual scales better defined, due apparently to the absence of a crust. Abdomen about as in minor, the punctures slightly smaller, the impression on fifth ventral of female poorly defined, and this impression feebly indicated in some male specimens also. The seventh funicular segment more transverse, on the average, than in minor.

Type.-A male (Cat. No. 41747, U.S.N.M.), $4.1 \mathrm{~mm}$. long with faint elytral vittae, and 20 paratypes.

Type locality.--Lincoln, Nebr. (Wickham).

Other localities: Nebraska (Lincoln, Shimek, Soltau, and Hubbard and Schwarz); Wyoming (Cheyenne, Soltau); Kansas (Fort Scott, Soltau), (Onaga, Wickham), (Onaga, Biological Survey, from stomach of meadow lark, Sturnella magna); Iowa (Sibley, Stoner), (Lake Okoboji, Buchanan), (Palo Alto County, Biological Survey, from stomach of toad, Bufo americanus).

As in minor, the proportions of the prothorax vary greatly, irrespective of sex, but in oblongus this part is almost always visibly shorter, especially in females. The eyes vary considerably in shape, but on the whole run more to the oval outline than in minor. Variations in the funicular segments are about as in that species.

The pronotal tubercles often show two or three small punctures in addition to the large, seta-bearing puncture at summit, indicating 
that they are made up of the coalescence of several smaller tubercles. Each main tubercle is covered by from four to six scales.

In this, and the next species, the predominant type of scale on abdomen is simple, but in most specimens a few plumose scales can be detected on third, fourth, or fifth segments. In minor the percentage of simple scales is much higher-at least I have seen no specimen of that species with as many plumose scales on abdomen as are often present on the other two.

\section{MESAGROICUS HERRICKI Pierce}

Lepidocricus herricki Pierce, Journ. Econ. Ent., vol. 3, 1910, p. 362; Proc. U. S. Nat. Mus., vol. 45, No. 1988, 1913, p. 420.-Blatchley and Leng, Rhyn. of N. E. Amer., 1916, p. 126 (a composite reference, including data for two more species).-Dury, Bull. Brooklyn Ent. Soc., vol. 18, 1923, p. 27 (probably refers to the species described in this paper as minor).

Twenty-two specimens (including three from the original type series). Length, 4-6 mm.; width, 2-2.7 $\mathrm{mm}$. Brown, the pale markings, when present, as in the two preceding except that the dorsum of elytra appears to be normally of a much darker and unmottled brown. About half the specimens with a large pale spot on third interval halfway down the declivity. Rostrum with a broad and deep median sulcus. The prothorax is narrower, compared to elytral width, than in oblongus. Measurements of these parts give the following average figures for six males and six females of each species: Width of prothorax is to width of elytra as 22.5 is to 36 (male herricki); as 27 is to 46 (female herricki); as 24 is to 36 (male oblongus); as 27 is to 41 (female oblongus). Abdomen coarsely punctate. Compared to oblongus and minor, herricki shows the following differences: Rostrum more deeply sulcate; eyes more prominent (more prominent in male); antennae stouter, the second funicular segment somewhat longer and in a few cases very nearly as long as first; pronotal tubercles much more prominent and more sharply defined; elytral setae longer; abdominal punctures larger; legs heavier, the tibial denticulations coarser.

The deep rostral sulcus, the prominent eyes and pronotal tubercles, and the coarse abdominal punctation are the distinctive characters of this species.

Localities.-Mississippi (Easter, the type locality), (Waveland, Soltau), (Picayune, W. M. Mingee); Alabama (Wadley, H. H. Smith) (Bay Minette, Biological Survey, from stomach of meadow lark).

\section{MESAGROICUS PLUMOSUS, new species}

One specimen. Length, $5.2 \mathrm{~mm}$. Width, $2.6 \mathrm{~mm}$. Brown, with pale vittae along sides of prothorax and on humeri. Rostrum as long as head, flat above, median groove narrow, surface either side 
strigosely sculptured. Head confluently punctate, eyes large, rather prominent, scape extending $3 / 4$ way across middle; seventh funicular segment very strongly transverse. Prothorax unusually short compared to elytra (20 to 67 ), pronotal tubercles strongly developed, nearly as sharply isolated individually as in herricki. Elytra with base deeply emarginate, somewhat depressed in region of scutellum, intervals broad and flat, setae as long as those in herricki, but thinner; abdominal scales very small, rounded, feebly to strongly plumose. Fifth ventral (female) with a distinct trasverse impression. Tibiae more dilated apically than in the three preceding species, the denticulations along inner edge feeble. Metepisternal suture fine.

Type.-A female (Cat. No. 41748, U.S.N.M.), labeled "Dept. Ent. Tex. A. \& M. C.; A. C. 171.",

\section{Type locality.-Texas (probably Mabank).}

The plumose scales and fine, dense punctation of abdomen are the distinguishing marks of this species. The elytral setae are slender and some of them, at first sight, appear to be bristlelike, but closer inspection shows that the tip of each is narrowly truncate.

\section{GROUP II}

Three species or subspecies comprise this group. The eyes are less convex than in either Group I or III. The scape reaches about $3 / 4$ the way across eye. The predominant body scales are simple, although well-developed plumose scales are present on certain areas of the abdomen. The pronotal sculpture is fundamentally of a tuberculate nature, though the tubercles are either so minute as to be properly called granules or so flattened that the resemblance to tubercles is lost.

KEY TO GROUP II

1. Pronotal sculpture consisting of irregular, flat-topped areas (evidently greatly flattened tubercles); prothorax rather narrow (averages 24 broad to 20.5 long) elongatus, new species.

1a. Pronotum with shining, punctate granules 2 .

2. Dimensions of prothorax as in elongatus .... _ var. nevadianus, new variety. 2a. Prothorax broader (22.5 broad to 18 long) _..._. var. incertus, new variety.

MESAGROICUS ELONGATUS, new species

Eight specimens. Length, 4.9-5.5 mm.; width, 2.01-2.3 mm. Elongate, slightly broader behind. Color above either uniform cinereous or cinereous and brown, the darker specimens with pale marks along sides of prothorax and on humeri. Antennae and legs reddish. Rostral groove broad and deep, usually extended back on to head, where it is fine. Eyes feebly to moderately convex. First funicular segment distinctly (may be nearly twice) longer than second, third to

${ }^{3}$ H. J. Reinhard, entomologist of the Agricultural and Mechanical College of Texas, has kindly sent the following information regarding accession No. 171: “ . . the specimen (bearing this label) ... was received from Mr. R. H. Small, Mabank, Tex., on May 5, 1903. No other notes are available, but it appears fairly certain that the specimen was collected in that locality." 
sixth moniliform, seventh transverse. Prothorax with sides feebly rounded, widest at or before middle, pronotal tubercles reduced to broad, irregular-shaped, flat-topped, barely elevated areas, each with a seta-bearing puncture, the entire surface normally covered with scales. Elytra with humeri evenly rounded, sides subparallel, sutural intervals, and in one specimen the third and fifth also, slightly prominent from base to middle; intervals broad, nearly flat and each with a row, regular or somewhat confused, of nearly straight, suberect, pale and brown setae; serial punctures small and rather close. Metepisternal suture visible. Abdominal punctures a little smaller than in oblongus and well separated. A few plumose scales can be detected here and there over most of the undersurface, but are not conspicuous except on fifth ventral, where they are numerous and deeply split.

Type.-A female (Cat. No. 41749, U.S.N.M.), $5.4 \mathrm{~mm}$. long, and 7 paratypes.

\section{Type locality.-The Dalles, Oreg. (Hubbard and Schwarz).}

This species looks considerably like a Sitona, due to the elongate, subparallel body and the bristling elytral setae.

\section{MESAGROICUS ELONGATUS var. NEVADIANUS, new variety}

One male (Casey collection). Length, $5 \mathrm{~mm}$; width, $1.9 \mathrm{~mm}$. Shape of elongatus, though slightly narrower, scales cinereous, setae pale brown and white. Antennae, eyes, and rostral groove about as in elongatus. Pronotal granules not prominent, each with a relatively large puncture occupying nearly the entire summit. Elytral intervals broad, none of them more prominent toward base. Humeri distinctly less prominent than in elongatus. First and second abdominal segments broadly concave in male, the concavity with the punctures denser, and the scales more abundantly plumose than in the corresponding area in male elongatus. Median lobe of male genitalia as in elongatus. Metepisternal suture obscured by scales.

Type locality.-Nevada.

Type.-Cat. No. 41750, U.S.N.M.

MESAGROICUS ELONGATUS var. INCERTUS, new variety

Two specimens (male and female). Length, 4.25-5 mm.; width, 1.7-2.1 $\mathrm{mm}$. Scales brown, elytra with a few, vague, pale mottlings, the usual lateral prothoracic line, upper eye border, and humeral spot pale. Eyes moderately prominent (male) or feebly so (female). First funicular segment fully twice (male) or less than twice (female) length of second; outer segments a little heavier than in elongatus. Pronotal granules about as in nevadianus. Metepisternal suture well defined. Plumose scales are numerous and highly developed on the abdomen of male but sparse and feebly plumose in female.

Type.-A female (Cat. No. 41751, U.S.N.M.), 41/4 mm. long, and 1 paratype.

Type locality.-Pullman, Wash. (J. W. Hungate, collector.) 


\section{GROUP III}

Of this group, only four specimens, apparently representing three species, have been seen. The scape extends $3 / 4$ way across eye, the latter moderately to strongly prominent. Elytral setae long, fine, acute at tip. Dorsal scales distinctly striate. The scales of under surface are all more or less plumose, those on abdomen being strongly so. Plumose scales are present also on the elytral flanks, a condition not found in either of the preceding groups. The punctures of the entire abdominal surface are small and dense, the species differing in this respect from all the others, except plumosus. The tibiae are obsoletely denticulate.

KEY TO GROUP III

1. Elytral scales contiguous to overlapping half their length; form narrow, subcylindrical (prothoracic to elytral width, 24 to 34 ); elytral setae rather long and conspicuous.............. hispidus, new species.

1a. Elytral scales, at most, only narrowly overlapping; form stouter _._._... 2.

2. Eyes moderately prominent; pronotum with fine, dense, subrugose punctation; elytral setae shorter (prothoracic to elytral width, 26 to 40 ).

strigisquamosus, new species.

$2 a$. Eyes very prominent, forming a hemisphere; pronotum with punctate granules; elytral setae longer (prothoracic to elytral width, 20.5-34).

ocularis, new species.

MESAGROICUS HISPIDUS, new species

Two females. Length, 4.9-5.1 mm.; width, 1.8-2 mm. Length to width of pronotum, 3 to 4 . Body subcylindrical, a little narrower behind; color pale brown, irregularly mottled with white on elytra. Rostrum with a distinct sulcus from between eyes to antennal insertion, surface either side finely, densely, subconfluently punctured; punctures on head still finer and denser. Eyes moderately prominent. Scape rather thick, distinctly biarcuate, the swollen apical portion setose but not squamose; first funicular segment thicker and longer than second (the two more nearly equal than in next two species), seventh distinctly transverse. Prothorax with sides rather strongly rounded, not constricted apically; pronotum with fine, dense and somewhat irregular punctation. Elytral scales contiguous to overlapping half their length, conspicuously striate, nearly concealing the rows of punctures; each interval with an irregular row of long brown and white setae. Impression on fifth ventral shallow. Plumose scales not so deeply split as in the next two species.

Type.-A female (Cat. No. 41752, U.S.N.M.), $4.9 \mathrm{~mm}$. long, and 1 paratype.

Type locality.-Oxnard, Calif. (Feeding on sugar beet. G. E. Bensel, collector.) 
One female specimen. Length, $5.4 \mathrm{~mm}$; width, $2.3 \mathrm{~mm}$. Moderately robust, scales coppery, paler as usual along sides of pronotum, upper margin of eyes, and on undersurface. Setae white. Rostral groove shallow basally, deeper in apical half, surface each side densely and roughly punctured; head densely punctured; eyes subcircular, rather prominent. Scape about as in hispidus; first funicular segment much stouter than second, and nearly twice as long, seventh more than twice as broad as long. Prothoracic proportions as in hispidus; pronotal sculpture consisting of punctate and very feebly elevated remnants of granules which coalesce in places, giving the surface a subrugose and irregular, roughly punctate appearance. Normally, this sculpture would be obscured by the coating of large, rounded, distinctly striate scales. Elytral setae in an irregular single row along each interval, those on fifth interval considerably confused; serial punctures small, largely concealed by the scales. Fifth ventral of female with a well-defined impression.

Type locality.-Altamont, Calif. (C. M. Packard, collector.)

Type.-Cat. No. 41753 , U.S.N.M.

\section{MESAGROICUS OCULARIS, new species}

One female specimen. Length, $3.9 \mathrm{~mm}$; width, $1.8 \mathrm{~mm}$. Body robust, less convex than usual, scales brownish coppery, paler around eyes and on undersurface. Head and rostrum, except apical $1 / 4$, densely, subconfluently punctate, the latter area with small, unevenly spaced punctures; rostrum lightly concave and with a fine median sulcus. Eyes subcircular. Scape setose, not squamose, in apical half; first funicular segment much stouter and twice as long as second, seventh strongly transverse. Prothorax transverse (5 to 4 ) sides feebly rounded in basal $2 / 3$, more strongly so toward apex, which is distinctly narrower than base; dorsum flattened for a short distance behind apical margin, pronotum with punctate and setigerous granules, and normally with a coating of rounded, contiguous, striate scales. Elytra deeply emarginate at base, intervals broad and flat; scales large, 3 or 4 together bridging an interval, closely appressed, varying from slightly separated to slightly overlapping, nearly obliterating in places the rows of rather small punctures; setae long, finer and more numerous than usual, in a confused row along each interval. Apical half of last ventral segment with a broad, transverse impression; first and second segments broadly and feebly concave. Undersurface densely and finely punctate.

Type locality.- "Cal." Horn Coll. H. 8308.

Type.-Deposited in Philadelphia Academy of Natural Sciences. 
The aspect of this species is one of broadness and flatness. The contiguous or narrowly overlapping elytral scales fail to entirely conceal the surface chitin, which is visible between the scales as numerous, minute, shiny-black points.

\section{EXPLANATION OF PLATES}

\section{Plate 1}

Fig. 1. Mesagroicus herricki, male.

2. Mesagroicus elongatus, female.

Plate 2

FIG. 1. Mesagroicus elongatus, female; $1 a$, fore tarsus; $1 b$, section of an elytral interval, showing scale arrangement.

2. Mesagroicus minor, female; $2 a$, fore tarsus.

3. Mesagroicus hispidus, female.

4. Mesagroicus oblongus; A, mandibular scar.

5. Mesagroicus herricki, male abdomen.

6. Mesagroicus strigisquamosus, female abdomen.

7. Mesagroicus minor, female, with deciduous mandibular piece in place.

8. Mesagroicus ocularis; $8 a$, section of an elytral interval, showing scale arrangement.

9-16. Antennae, female, of minor, 9 ; oblongus, 10; herricki, 11; plumosus, 12; elongatus, 13 ; hispidus, 14 ; strigisquamosus, 15 ; and ocularis, 16.

17. Diagrammatic sketch to illustrate elytra with a perpendicular basal margin.

18. Same, to show basal margin perpendicular at sides only.

19-22. Median lobe, side view, of male genitalia of minor, 19; oblongus, 20; herricki, 21 ; and elongatus, 22 ; $a$, dorsal view; $b$, view of apical $1 / 4$ of lobe, from a point directly above this portion.

23. Fore tibia of plumosus.

24. Hind tibia of same.

25. Fore tibia of strigisquamosus.

26. Hind tibia of same. 


\section{$2 \mathrm{BHL}$ Biodiversity Heritage Library}

Buchanan, L. L. 1929. "North American species of the weevils of the otiorhynchid genus Mesagroicus." Proceedings of the United States National Museum 76(2801), 1-14. https://doi.org/10.5479/si.00963801.76-2801.1.

View This Item Online: https://www.biodiversitylibrary.org/item/88912

DOI: https://doi.org/10.5479/si.00963801.76-2801.1

Permalink: https://www.biodiversitylibrary.org/partpdf/65580

\section{Holding Institution}

Smithsonian Libraries

\section{Sponsored by}

Smithsonian

\section{Copyright \& Reuse}

Copyright Status: Public domain. The BHL considers that this work is no longer under copyright protection.

This document was created from content at the Biodiversity Heritage Library, the world's largest open access digital library for biodiversity literature and archives. Visit BHL at https://www.biodiversitylibrary.org. 